\title{
The Distribution of Marine Plankton.
}

IN order to endeavour to co-ordinate the work of the many naturalists who make use of the tow-net round the coasts of the British Isles during the year, the following circular has been issued. The list of organisms, upon the presence or absence of which information is desired, contains only such as can be quite easily recognised. The scheme must be regarded as more or less experimental for this year, with a view to finding out what can be done in this direction.

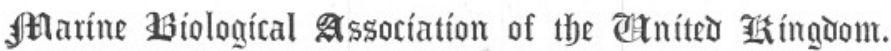

\section{The Laboratory, Plymouth, December soth, 1896.}

Sir,-Many of the organisms commonly found in the plankton of the sea around the British coast exhibit remarkable variations in their relative abundance at particular localities from year to year, but little is known as to the extent and causes of such variations. As a number of naturalists make use of the tow-net at many places round the coast, especially during the summer, much valuable information would be obtained if in all cases records were kept of the presence or absence of a limited number of the commoner species, and these records subsequently brought together.

In the hope that you may be willing to assist in obtaining such information, I enclose a short list of organisms, the presence or absence of which I would ask you to record at any locality and as often as you may be using the tow-net during the year 1897. The records may be forwarded to me from time to time, and all should be sent in before January 31st, 1898.

Additional copies of the list will be sent, if desired, and your assistance is requested in inducing other naturalists to co-operate in making the records.

I am, Sir, yours faithfully,

E. J. Allen,

Director. 


\section{LIST OF SPECIES.}

List of Species to be recorded whenever and wherever possible, during the year 1897:-

Halosphaera viridis.

Noctiluca miliaris.

Aurelia aurita (including Ephyrae).

Agalmopsis.

Muggicea atlantica.

Hormiphora plumosa.

Beroe.

Tomopteris.

Anomalocera Patersoni.

Doliolum.

Salpa.

Where the generic name only is given in the above list, the specific name of the specimens taken should be added. Should any doubt exist, preserved specimens should be kept.

In making a record the following should be stated:-

Date.

Hour.

Locality. (With as much accuracy as possible.)

DEтTH. (Depth of water, and maximum depth at which net has been worked.)

Quantity $\begin{cases}0 . & \text { Absent. } \\ \text { 1. } & \text { Few only. } \\ 2 . & \text { Moderately plentiful. } \\ \text { 3. } & \text { Exceptionally abundant. }\end{cases}$

Observations on the temperature of the sea, and notes on wind, tide, etc., will also be of value.

Records to be sent in before January 31st, 1898, or forwarded from time to time to the Director, Marine Biological Association, Plymouth. 